\title{
Feminist Narrative Approaches to Security
}

Akanksha Mehta \& Annick T.R. Wibben

\section{Introduction}

In Borderlands/La Frontera: The New Mestiza, queer Chicana feminist activist and scholar Gloria Anzaldúa writes about how the world is not safe: "We shiver in separate cells in enclosed cities, shoulders hunched, barely keeping the panic below the surface of the skin, daily drinking shock along with our morning coffee, fearing the torches being set to our buildings, the attacks in the streets" (1999 [1983]: 42). Women, especially those on the margins of societies stratified by the intersections of gender, race, class, sexuality and more, have often found themselves 'unsafe' in a variety of ways - "when her own culture, and white culture, are critical of her; when the males of all races hunt her as prey" (ibid.). Notes, Anzaldúa, "alienated from her mother culture, 'alien' in the dominant culture, the woman of color does not feel safe within the inner life of her Self. Petrified she can't respond, her face caught between los intersticios, the spaces between the different worlds she inhabits" (ibid.).

Anzaldúa's narratives of (in)security and borders do not find space in most literatures in security studies. Yet, for feminist scholars who study security, voices like hers are crucial to not only understanding the politics of gender, identity, and the everyday but the very making and unmaking of the meanings and practices of security. Anzaldúa wants "the freedom to carve and chisel my own face, to staunch the bleeding with ashes, to fashion my own gods out of my entrails. And," she goes on, "if going home is denied me then I will have to stand and claim my space, making a new culture - una cultura mestiza - with my own lumber, my own bricks and mortar and my own feminist architecture" (1999 [1983]: 44). As feminist scholars maintain, 
until hierarchies of gender and "other hierarchies associated with class and race are dismantled and until women have control over their own security a truly comprehensive system of security cannot be devised" (Tickner 1992: 30).

As (in)securities shift and slide according to contexts, a narrative approach to gender and security offers crucial insights where "the differences among stories and storytellers, which characterize personal narratives, are explicitly acknowledged" (Wibben 2011: 86). Paying attention to (personal) narratives shows how identity and security implicate each other in the everyday: In her exploration of the life stories of poor Mayan women at the end of the civil war in Guatemala, Maria Stern (2005) finds that their experiences with (in)securities were shaped by the varied relations to the dominant Ladino community and the Guatemalan state as well as within the household, the Mayan community, and the fincas where the women lived and worked. Paying this kind of close attention also reveals that emphasizing only some identities (for example, national identities, in the case of dominant frameworks of national security) privileges certain kinds of security over others, marginalizing, ignoring, and silencing a variety of actors and their lived experiences.

This chapter will discuss narrative approaches to gender and security to show how challenging dominant modes of thinking security needs to entail attention to gender and other intersectional markers of identity that are intimately involved in shaping that which is to be secured in the first place. While it will dwell mostly on how narratives can be used a mode of analysis, this chapter will also consider how narrative as a mode or form of writing can reshape understandings of security. 


\section{What are narratives and what do narratives do?}

A narrative, put simply, is "a way of making sense of the world around us" (Moulin 2016:138). Through narratives, we engage with the world, produce meanings and knowledges, articulate our intentions and politics, and justify our actions (Wibben 2011:2). They, thus, "tell us a lot about the limits and possibilities of political life, since they articulate particular worldviews, create and enable certain political subjects, and (re)produce specific understandings about facts, relations, and formations" (Moulin 2016:138). As discursive formations in motion, narratives are sites where power is exercised and worlds are investigated as well as invented (Wibben 2011:2). Narratives can insist on grand singular meanings that confirm social orders and power structures but can also disrupt overarching discourses and understandings of the world, challenging authoritarian structures and hierarchies (Shapiro 1998:19).

Traditional security narratives organise themselves around (nation) states and their sovereignty, treating the two as "ontologically stable and unproblematically identifiable" (Wibben 2011: 72). These narratives limit how we think about security and disallow the crucial questions: What is security? Whose security is important? How is security achieved? How do multiple insecurities intersect? (ibid: 65). They also simultaneously allow the powerful to frame any issue/event in terms of security and to exclude a plethora of voices, contradictions, contexts, contesting claims, interpretations, experiences, and subjectivities. Approaches in critical security studies have worked to address the silences in traditional security narratives by moving beyond the state as the referent of security (e.g. Booth 1991, Buzan 1991, Wæver 1995). Elaborating on the processes and practices of security, some of this scholarship highlights the "contextual nature of security meanings" and 
creates space for debates on the politics of securitization (Wibben 2011: 78). The Copenhagen school (Buzan et al. 1998), for example, applies speech act theory to processes and practices of security to elaborate on securitization and desecuritization as processes that frame and de-frame a situation/issue/event in terms of security. Notably these processes rely on security agents who are subjects that are seen as authorized and legitimate to frame an issue or event as a security situation - an important issue for feminist scholars.

Problematically, the changes proposed by some of these approaches are "largely additive rather than subversive" (Wibben 2011:81) as they aim to broaden and deepen security narratives without investigating, challenging, and displacing their fundamental structure, foundations, and the politics of the very meaning of security. For example, while these approaches include gendered readings of security with women as referents of security, their analyses rely on identifying security agents, i.e. subjects that have the ability to speak and to be heard (Hansen 2000: 294). While these critical approaches move beyond the state as the (only) security agent, they continue to make liberal assumptions about political subjectivities and the politics of speaking, listening, and being heard. Where will everyday narratives of security and insecurity find place in these analyses? Can marginalised groups (such as women of colour, working class women, lower caste women, trans* women, etc.) become authorized agents of security? Are their narratives of security/insecurity irrelevant? Would Anzaldúa's (1999) words and the experiences of poor Mayan women who Stern (2005) researches be heard in these frameworks? What other sites of security narratives (e.g. Daigle 2015, Park-Kang 2014, Shepherd 2013) are we missing? How can feminist and gendered voices be considered worthy of speaking and be heard if the very meaning and politics of security are undisturbed? 
A feminist narrative approach to security studies addresses the aforementioned shortcomings in traditional and certain critical approaches and offers new ways of thinking about security, methodologies, methods, and research ethics, as well as the practices and politics of academic knowledge production (Wibben 2011, 2016a, 2016c). It takes into account everyday gendered experiences and stories of (in)security and violence, paying attention to the multiplicity of identities and subjectivities and how they shape our personal-political lives. It recognizes that narratives of (in)security are "untidy" and non-linear and that feminist knowledge production can only occur by paying attention to their twists, turns, messiness, surprises, and contradictions (Stern, 2005: 12; Zalewski 2008: 42-61).

A feminist narrative approach to security allows scholars to dissect hegemonic (and often oppressive) understandings of world politics and political violence and to challenge dominant stories by writing politics and security from multiple, alternative, and decolonial vantage points. Troubling the very meaning of security and what it means to be secure, it dispels the dichotomy between security and insecurity. It acknowledges that there "is not one version of security, but how the security of some is deeply implicated in, and even predicated upon, insecurity for others" (Wibben 2011: 91). For example, the Hindu right-wing and Zionist settler women that Mehta (2015, 2016) researches, find utmost safety, peace, mobility, and agency only at times of heightened violence and tensions with the 'other' and their communities. Their security (from its discourses and policies to its everyday practices) hinges upon moments of rampant instability and furthers violence and insecurity in the lives of their designated 'others'.

Finally, a feminist narrative approach to security interrogates not only the stories but also the intersectional positionalities of the storytellers, etching out 
silences, emotions, and voices that remain unspoken and unheard and addressing the politics of speaking, listening, and being heard (Wibben 2011). Feminist scholars such as Anzaldúa have long employed narratives to write the lives and politics of women and their experiences of identity and (in)security. However, these narratives have not found a space in the canons of academic work in political science, international relations, and security studies. A feminist narrative approach to security studies not only brings such stories to the core of scholarship but also questions the mechanisms and reasons for their silencing. In doing so, it also acknowledges that in our writing and analyses of narratives of security, some stories will always be unspoken and unheard.

\section{Using Narratives in Feminist Research}

There are two key ways in which narratives are used in the study of gender and security - as a mode of analysis and a form/style of writing and expression. As mentioned in the previous section, as a mode of analysis, narratives offer a way of examining the production of meanings and politics in our research on gender and security as well as in the words and actions of our interlocutors. Narrative theory offers a toolbox to formulate, compare and challenge different interpretations of events and actions, and narrative analysis can help to elaborate on the actualization of interpretation and its conditions of possibility thus helping clarify value judgements and the politics of telling stories (Wibben 2011, 2016a; Moulin 2016).

As a form or style of writing, narratives offer a mode of knowing and knowledge production that moves far away from positivist knowledge production, thereby providing means of epistemological critique and pluralism in the social sciences (and especially in politics, IR, and security) 
research. Feminist narrative writing challenges the rigidities, norms, and boundaries of 'disciplines', questioning the very ways in which academics have been trained to think, speak, and write and providing alternate forms of engagement where theories are intertwined with stories. Feminist narrative writing also reclaims "the importance of everyday life to understanding global processes...presenting alternative voices (and consequently unheard stories) of [ordinary] peoples, places, and events that are central to the unfolding of international affairs (Moulin 2016: 145). Most importantly, as feminists of color from Anzaldúa to Audre Lorde (1983, 1984) have long explored and has more recently been discussed by Naeem Inayatullah \& Elizabeth Dauphinee (2016; see also Dauphinee 2013), narrative writing offer a means of inserting the researcher and her subjectivities into the research, forcing scholars to "consider their own complicities, partialities, and problematic placements in the unfolding of the plots that constitute their argument/understanding of particular international problems" (Moulin 2016: 145).

\section{Gendered Security Narratives}

When we study security, one of the key concerns and questions is the frame through which we perceive the world. After all, we need to know which issues and events Security Studies should be concerned with, what security means, and who is being secured. To this end, students of security are generally taught particular security logics (Huysmans 1998, 2006) which find their expression in "a fairly closed narrative structure consisting of four main elements: threats locating danger, referents to be secured, agents to provide security, and means to contain danger" (Wibben 2011: 66). These security logics, which operate also in critical security scholarship, continue to limit the meanings of security, the politics of these meanings, and the kinds of stories 
that can be told and that are heard. Framing security in a manner different from the above-mentioned four-fold structure tends to not get the desired attention. In what follows, we will discuss three examples that illustrate the workings of feminist narrative approaches to gender and security. The first two examples are centred around the events of 9/11, its aftermath, and the 'war on terror'. The final example is centred on the Maoist movement in contemporary India.

In a televised address the night of $9 / 11$, Bush provided the official narrative of the day, framing the events in a way in which they were ordered and comprehensible, legitimising the responses of the state and limiting any alternative narratives (Wibben 2011: 57). Danger was located (e.g. Al-Qaida and other 'terrorist' organisations as well as states such as Afghanistan and Iraq); referents that were to be secured were identified (the 'American' people, their 'way of life', and their interests referred to as 'our people' and 'our nation'); agents that were authorised to speak about security and provide security were identified (the U.S. state and military); and the means to contain danger were unleashed (the 'war on terror' and its racialized draconian policies, invasions of Iraq and Afghanistan, torture and detention mechanisms, etc.). By framing the events along this familiar narrative structure, the 9/11 narratives paint the events as "'uncaused' cause" (Zehfuss 2003) and work "to preclude certain kinds of questions, certain kinds of historical inquiries, and to function as a moral justification for retaliation" (Butler 2004: 4).

A feminist narrative approach offers new ways to understand how the gendered, racialized, and incomplete narrative of September 11, 2001 did not begin and end on that day. Bush's address to the nation and subsequent 
official 9/11 narratives, while focusing on the loss of 'American life', attack on 'American values', and the urgent to need to protect 'our nation', omitted narratives that questioned U.S. exceptionalism, liberalism, the limitations of pluralism and multiculturalism in the U.S., and the meanings of what it means to be 'American' or hold 'American values'. Feminist and postcolonial studies scholar Gayatri Spivak (1988: 287) argues that by "measuring silences" and what is left unheard, we are "investigating, identifying, and measuring... the deviation' from an ideal that is irreducibly differential". A feminist narrative approach to 9/11, thus, not only analyses how and why these omissions were deployed to build a singular story that benefits certain (draconian) security responses but also makes space for silenced stories, emotions, bodies, reactions, and aftermaths to $9 / 11$; from the racial discrimination and attacks faced by Muslim (and Sikh) men and women (most of whom were also 'American') to post traumatic stress amongst those returning from the frontlines of the 'war on terror.'

Furthermore, a feminist narrative approach to the aftermath of 9/11 also examines how gender was used to make the case for military intervention and invasion of Afghanistan and Iraq (e.g. Hunt \& Rygiel, 2006). For example, to make the case for intervention in Afghanistan, Laura Bush, then first-lady of the U.S., used the weekly presidential radio address on November 17, 2001 to claim that "the fight against terrorism is also a fight for the rights and dignity of women" and that ousting the Taliban would be a step toward this goal of saving Afghan women and girls. This co-optation of women's rights issues and of a feminist agenda in the theatre of war, and the orientalist assumptions and narratives it relies on, must be interrogated. Many of the problems experienced by the Afghan population, and women in particular, were the outcome of decades of war in which the U.S. was deeply implicated and 
hence the sudden '“focus on women's liberation in Afghanistan [seems] little more than a cynical ploy"' (Stabile \& Kumar, 2005, p. 765). What is more, Dana Cloud's analysis of photographs of the 'War on Terror' published in Time magazine and Time.com in the year following September 11, 2001, reveals how the photo essays "construct paradigmatic binary oppositions, encourage viewers to adopt a paternalistic stance toward Afghan women, and offer images of modernity, aligned with light, in contrast to the darkness of chaos and backwardness" (Cloud 2004: 290-91).

When doing narrative analysis, the point of view from which the elements of a story are presented is important. Presenting the story from a particular point of view results in a certain focalization, that is the relation between who perceives and what is perceived (Bal 1997, p.8). A second example of feminist narrative analysis from the 'war on terror' that keenly highlights the abovementioned process of focalization involves the representations of the U.S Marine Corps Female Engagement Teams (FETs). FETs are all female teams, generally attached to a male infantry battalion, who a charged with engaging Afghan women as women as part of the effort to 'win hearts and minds' in US counterinsurgency practices in Afghanistan. When Keally McBride \& Wibben (2012) analyzed representations of FETs in official documents as well as worldwide media reports, they found that none of the material available even considered the point of view of Afghan women who were supposed to be benefiting from the actions of women in FETs. Only one account, written by the team who came up with the idea for FET (Pottinger, Jilani \& Russo et al., 2010), features an unnamed Afghan elder who is quoted saying, "“your men come to fight, but we know the women come to help"' (p.4). Even seemingly progressive accounts, such as that of Ann Jones for The Nation (2010), while drawing out some of the broader context of Afghan women's lives and its material realities end up not featuring a single Afghan voice (Wibben 2016b). 
Narratives of women in FETs highlight the gendering of war, conflict, and counterinsurgency, where gendered assumptions about men, women, and their roles (with men as combatants and women as peacemakers) are solidified and used as the basis of policy (Khalili, 2011). With FETs as the focal point of these narratives and the subsequent silencing of Afghan women's lives, stories, and experiences, they also highlight the inherent power hierarchies of the 'war on terror' that are built on orientalised gendered and racialized stereotypes of the Afghan women (and men). Similarly, Melanie Richter-Montpetit's (2007, 2016) feminist queer analyses of the racialized/sexualized torture of detainees by the US military at the Abu Ghraib prison (officially known as the Baghdad Central Prison) in Iraq highlights the orientalist gendered and racialized stereotypes of Iraqi men (and women) and the colonialist/civilizational workings of the violence of the 'war on terror'.

What we see through this second example of the FETs (and Abu Ghraib) is that even feminist narratives can have trouble overcoming colonialist framings that do not pay sufficient attention to multifaceted local contexts and 'replicate problematic aspects of Western representations of Third-World nations or communities, aspects that have their roots in the history of colonization' (Narayan, 1997, p. 45). Indeed this particular kind of embedded feminism (Hunt 2006) has proved deeply divisive among feminists as it has also provided further evidence that "the Third World Woman" (Mohanty 1988) still cannot speak - or at least cannot be heard. Beyond the issue of colonialist representation there is also the question of not just the gendered but racialized and orientalist frames at play in these latest attempts to save brown women from brown men (Spivak 1988, Bhattacharya 2008). As far as the "war on terror" narrative is concerned (see also Wibben 2016b) - it is 
clearly not enough to simply ask for women to be included, whether as objects or agents of intervention, but we always have to ask how that inclusion takes place. Narrative analysis can help tease out the nuances of particular representations and provide revealing evidence.

A third example that highlights the necessity of a feminist narrative approach to security is the political violence and struggle of the Maoist/Naxalite movement in India and the question of women's participation in it. United under the umbrella of an organisation called the Communist Party of India (Maoist), the Naxalite movement is a group of women and men from economically and socio-culturally marginalized populations. Members of the group perceive the Indian state as a neoliberal and upper-caste oppressor that marginalises, loots, and kills in its quest for natural resources, land, and political power (Parashar 2013: 622). The male leadership of the party and the movement insist that the 'people's war' they are waging also aims to obliterate patriarchy and the subjugation of women (Mehta 2012: 203). Dominant security narratives perpetuated and supported by the Indian state as well as traditional security analyses construct the Maoists/Naxalites as 'deviant' citizens that are the greatest internal security threat to the country (Ramana 2008).

While these analyses are predominantly gender-blind, they remain perturbed by the participation of women in armed conflict and violence, theorising women as "victims" of male cadres, who are not only instrumentalized into joining the movement but are also routinely subjected to sexual violence within the movement (Mehta 2012:203). Left-wing and feminist activist responses to these dominant security narratives examine the larger structural violence faced by marginalised communities across India and highlight the brutality of the state's military/paramilitary excesses in the name of counter- 
insurgency and security (Bhatia 2006; Sundar 2006; Roy 2010). Feminist narrative approaches that draw on grassroots, activist, discursive, and ethnographic knowledges and are grounded in the intersectionality of gender, caste, and class (can) offer an even more nuanced understanding of the Maoist movement and the experiences and politics of its members. Problematising knowledge claims and binaries put forth by both, the state and the male leadership of the Maoist/Naxalite movement, feminist narrative research seeks to find the difficult "middle path" to understand women's participation, roles, and politics in this armed conflict (Parashar 2016: 42). Feminist scholars not only question the state's conception of citizenship, (in)security, threat, violence, development and its counterinsurgency excesses, but also draw out the gender and caste based contradictions, exclusions, and violence within the Maoist movement (Mehta 2012; Parashar 2016).

Capturing women's multiple experiences in this movement in a "war collage" that blurs and juxtaposes "high and low politics, places, and people" (Sylvester 2013: 126), feminist narrative approaches assert that here "there are no linear stories, no dominant emotion, no binaries between victimhood and agency, and plenty of gray areas between their [women insurgents'] traditional gender roles as wives and mothers and as combatants and militants" (Parashar 2016: 45). Paying attention to silences, emotions, bodies, the everyday lives and experiences of Maoist women, and the relationships between the researcher and the researched, feminist narrative approaches examine interviews with Maoist women as well as various other sources such as their songs, poetry, fiction, visuals, films, autobiographical writings, and political speeches and commentaries (Mehta 2012; Parashar 2016). They assert that although this armed conflict enables certain shifts in traditional gender norms and roles and opens up spaces for mobilisation of female cadres, 
women in the movement were largely foot soldiers who provided logistical support and cultural legitimacy while being excluded from larger decisionmaking and leadership roles in the party and movement (Mehta 2012; Parashar 2016). Women joined the movement for various personal-political reasons (including ideology, unemployment, and as a means to resist patriarchies in society and find 'safety' and 'security' from state violence). However, they continued to face both, class and caste patriarchies and violence in 'mainstream' society as well as various exclusions and violences within the movement (ibid). Their participations were varied and adapted to the overall male-formulated strategies of the movement. Women also departed the movement for various reasons, including the exclusions they faced within the party. Women's bodies in the movement are thus sites of a continuum of violence, which also extends to the anti-Maoist and counterinsurgency operations of the state. As the Indian state seeks to 'eliminate' or 'rehabilitate' the 'deviant' Maoist citizens, women bear the brunt of state harassment, abuse, torture, sexual violence, and exploitation that is rampant in the military/paramilitary operations (ibid).

As all of the three aforementioned examples have demonstrated, feminist narrative approaches uncover the contested and changing meanings of security and insecurity and highlight how these intersect with categories such as gender, class, caste, race, ethnicity, religion etc. In doing so, gendered security narratives also address bigger questions about power in the disciplines of security studies and international relations (as well as gender studies) - Whose stories get told and why? Whose narratives are excluded? What binaries are used to sustain stories and why? What is lost with these exclusions and binaries? (Parashar 2016: 51). These are questions without which we cannot begin to fully comprehend the world we inhabit. 


\section{Limits of Narrative Approaches}

Gendered security narratives tell complex and difficult stories of the world around us. As mentioned in the earlier sections of this chapter, gendered security narratives enable different ways of thinking about the world and the politics of security, violence, and peace. However, scholars who engage with these narratives and who use narrative as a form of writing and knowledge production (must) grapple with a variety of ethical dilemmas that function as the possible limitations of these approaches.

Here, we must begin by asking the basic questions: Whose stories are we telling? To whom? Who benefits from these narrations and analyses? Why are we telling these stories? How are we telling them? Since there will always be stories that continue to be untold or unheard, we need to further examine why they are omitted. We should ask: What stories are we choosing not to tell and why? Whose voices - and therefore stories - are we unable to hear because of our biases? As we offer varied ways of thinking about the world and shed light on a multitude of power hierarchies, positionalities, privileges, and politics, we must always remember in the process of telling and analysing stories, we remain hindered by blind spots around the intersections of gender, race, sexuality, class, caste, ability etc. As shown by the examples in the previous sections, feminist analyses are also be limited and at times reproduce problematic assumptions.

We need to acknowledge that narratives about security are not easy to read and write. They involve trauma, violence, intense emotions, embodied experiences, and stories that are often far out of our comfort zones. How do mediate someone else's experience of security, of conflict, of violence, of peace, and of trauma while acknowledging the distortions we bring to it? How do we write emotions and embodied politics? What are the effects of 
(secondary) trauma on our researcher-selves? Especially when we write autoethnographic narratives of security, how do we address the need for self-care? At the same time, how can we prevent our exercises in knowledge production from turning into practices of navel-gazing and self-indulgence? Finally, it is important to remember that even though we challenge dominant narratives about security, we also continue to be complicit in the production and maintenance of various gendered and racialized hierarchies inside and outside the academy. How do we engage with and subvert hegemonic narratives while acknowledging our role in their perpetuation?

\section{Conclusion}

Overall, critical feminisms take seriously the multiplicity of women's lives, interests and ideas and highlight the difficult political questions at stake. As Carol Cohn (2013, p. 2) highlights in relation to war: "The diversity of women's experiences of and relations to war are due to both diversity among women and among war." Additionally, "women are also thinkers who make their own sense of the multiple social, cultural, economic, and political forces which structure their lives" (ibid.). This multiplicity consequently "gives rise to contradictory interests among women [which means that] attempts to generalize about 'women and war' [...] always run the risk of doing conceptual violence to the realities of women's lives" (ibid.). To maintain the necessary contextual specificity, as well as to be able to offer multiple points of view and highlight complexities, we argue for sharing/ creating a multiplicity of narratives. Crucially, when multiple narratives circulate, there is also room to "'oppose the terms of power and authority circulated and recirculate in discourse'" (Shapiro 1988 , p. 19) by highlighting different storylines and insisting that they do not all have to align neatly. 
It is important to stress - as we have done above - that thinking about gendered insecurities through narratives is actually not a new approach, but rather a really old one. The work of Anzaldúa, quoted at the outset of this chapter, is one example of writing on the identity-security nexus integrating not just poetry, but also writing in a multiplicity of languages to capture the variety of narrative standpoints. I, Rigoberta Menchú (Menchu 1983) is another example in the genre of testimonio that is not a recognizable text about security as far as Security Studies is concerned, but it clearly deals with the relevant issues. Meanwhile the work of Algerian novelist Assia Djebar whose effort to write disappeared resistance fighter Zoulika Oudai back into existence (Doubiago 2016) further reveals the importance of the literary imagination for

feminist work rethinking security. Indeed, it is possible to read much of women's storytelling in this way. That this work has long existed but is not, generally, read as pertaining to security (even in feminist circles) is indicative of broader disciplinary questions about whose work and in which formats gets taken seriously. The increasing attention to narrative(s) in (Feminist) Security Studies, and IR more broadly, is hence both exciting and revealing.

\section{Bibliography}

Anzaldúa, Gloria (1999 [1987]) Borderlands/ La Fronterra: The New Mestiza. 2nd Ed. San Francisco: Aunt Lute Books.

Bal, Mieke (1997) Narratology: Introduction to the Theory of Narrative. 2nd Ed. Toronto: University of Toronto Press.

Bhatia, Bela (2006) “On Armed Resistance." Economic and Political Weekly. 41 (29), 22 Jul, 2006 
Bhattacharya, Gargi (2008) Dangerous Brown Men: Exploiting Sex, Violence and Feminism in the 'War on Terror'. London \& New York: Zed Books.

Booth, Ken (1991) Security and Emancipation. Review of International Studies 17(4): 313-26.

Bush, Laura (2001) Radio Address by Laura Bush to the Nation on November

17. White House. Online. Available: https://georgewbushwhitehouse.archives.gov/news/releases/2008/02/20080201-2.html [accessed Jan 10, 2017]

Butler, Judith (2004) Precarious Life: The Powers of Mourning and Violence. London: Verso.

Buzan, Barry (1991) People, States, and Fear: An Agenda for International Security Studies in the Post-Cold War Era, 2nd ed, New York: Harvester-Wheatsheaf.

Buzan, Barry, Ole Waever and Jaap de Wilde (1998) Security: A New Framework for Analysis/ Boulder: Lynne Rienner.

Campbell, David (1998) Writing Security: United States Foreign Policy and the Politics of Identity, 2nd ed, Minneapolis: University of Minnesota Press.

Cloud, D.L. (2004) 'To Veil the Threat of Terror': Afghan Women and the $<$ Clash of Civilizations $>$ in the Imagery of the U.S. War on Terrorism. Quarterly Journal of Speech 90 (3): 285-306.

Cohn, Carol, ed (2013) Women \& Wars. Cambridge: Polity Press

Daigle, Megan (2015) From Cuba with Love: Sex and Money in the Twenty-First Century. Berkeley: University of California Press.

Dauphinee, Elizabeth. (2013). The Ethics of Autoethnography. Review of International Studies, 36(3): 799-818.

Der Derian, James (1995) The value of security: Hobbes, Marx, Nietzsche, and Baudrillard. In: Ronnie D. Lipschutz (ed) On Security: New Directions in World Politics. New York: Columbia University Press.

Dillon, Michael (1996) Politics of Security: Towards a Political Philosophy of Continental Thought. London: Routledge. 
Doubiago, Shawn (2016) Algerian feminist methodologies of recovery, redress and resistance in Assia Djebar's La Femme Sans Sepulture (2002). In: Annick T.R. Wibben (ed) Researching War: Feminist Methods, Ethics and Politics (pp. 239-257). London \& New York: Routledge.

Hansen, Lene (2000) The little mermaid's silent security dilemma and the absence of gender in the Copenhagen school. Millennium: Journal of International Studies, 29 (2), 285-306.

Hunt, Krista (2006) 'Embedded Feminism' and the War on Terror. In: Hunt, Krista \& Kim Rygiel (Eds). (En)Gendering the War on Terror: War Stories and Camouflaged Politics (pp. 51-71). Aldershot: Ashgate.

Hunt, Krista \& Kim Rygiel (Eds) (2006) (En)Gendering the War on Terror: War Stories and Camouflaged Politics. Aldershot: Ashgate.

Huysmans, Jef (1998) Security! What do you mean? From concept to think signifier. European Journal of International Relations 4 (2): 226-55.

-- (2006) The Politics of Insecurity: Fear, Migration and Asylum in the EU. London \& New York: Routledge.

Inayatullah, N. \& Dauphinee, E. (Eds.). (2016). Narrative Global Politics: Theory, History and the Personal in International Relations. New York, NY: Routledge.

Jones, Ann (2010) Woman to Woman in Afghanistan. The Nation. 15 November: 11-15. Available: https://www.thenation.com/article/womanwoman-afghanistan/ [accessed Jan 10, 2017].

Lorde, Audre (1983). Zami: A New Spelling of My Name. Trumansburg, New York: The Crossing Press.

Lorde, Audre (1984). Sister Outsider: Essays and Speeches. Trumansburg, New York: The Crossing.

Menchú, Rigoberta (1983) I, Rigoberta Menchú An Indian Woman in Guatemala. London: Verso.

Mohanty, Chandra Talpade (1988) Under Western Eyes: Feminist Scholarship and Colonial Discourses. Feminist Review 30 (1): 61-88. 
McBride, Keally \& Annick T.R. Wibben (2012) The Gendering of Counterinsurgency in Afghanistan. Humanity 3(2): 199-215.

Mehta, Akanksha (2012). “No Revolution Without Women, No Liberation Without Revolution: Women in India's Maoist Movement " in More than Maoism: Politics, Policies and Insurgencies in South Asia, Ed. Jeffrey, Robin, New Delhi: Manohar Publications.

-- (2015) The aesthetics of "everyday" violence: narratives of violence and Hindu right-wing women. Critical Studies on Terrorism, 8(3), 416-438.

-- (2016) Right-Wing Sisterhood: Everyday Politics of Hindu Nationalist Women in India and Zionist Settler Women in Israel-Palestine. Unpublished PhD Dissertation, SOAS, University of London.

Moulin, Carolina (2016). Narrative. In: Mhurchú, Aoileann Ní and Shindo, Reiko (Eds.) Critical Imaginations in International Relations (pp. 136-152). New York: Routledge

Narayan, Uma (1997) Dislocating Cultures: Identities, Traditions, and Third World Feminism. London \& New York: Routledge

Parashar, Swati (2013) “What wars and 'war bodies' know about international relations" Cambridge Review of International Affairs, 26:4, 615-630,

-- (2014) Women and militant wars: The politics of injury. London \& New York: Routledge.

-- (2016) Women and the matrix of violence: A study of the Maoist insurgency in India. In: Annick T.R. Wibben (ed) Researching War: Feminist Methods, Ethics and Politics (pp. 38-56). London \& New York: Routledge.

Park Kang, Sungju (2014) Fictional International Relations: Gender, Pain and Truth. London \& New York: Routledge.

Pottinger, Matt, Hali Jilani \& Claire Russo (2010) Half-Hearted: Trying to win Afghanistan without Afghan Women. Small Wars Journal. Available: http://smallwarsjournal.com/jrnl/art/trying-to-win-afghanistan-withoutafghan-women [accessed Jan 10, 2017]. 
Ramana, P.V. (2008). The Naxal Challenge: Causes, Linkages, and Policy Options. New Delhi, India: Pearson

Richter-Montpetit, Melanie (2007) Empire, Desire and Violence: A Queer Transnational Feminist Reading of the Prisoner 'Abuse' in Abu Ghraib and the Question of 'Gender Equality'. International Feminist Journal of Politics 9 (1): 38-59.

--(2016) Militarized Masculinities, Women Torturers and the Limits of Gender Analysis at Abu Ghraib. In: Wibben, Annick T.R. (Ed.) Researching War: Feminist Methods, Ethics \& Politics (pp. 92-116). London \& New York: Routledge.

Roy, Arundhati (2010) "Walking with the Comrades." Outlook Magazine. 29 March 2010. Available:

http://www.outlookindia.com/magazine/story/walking-with-thecomrades/264738 [accessed Jan 25 2017]

Shapiro, Michael J. (1998) The Politics of Representation: Writing Practices in Biography, Photography, and Policy Analysis. Madison: University of Wisconsin Press.

Shepherd, Laura (2013) Gender, Violence and Popular Culture: Telling Stories. London \& New York: Routledge.

Spivak, Gayatri C. (1988) Can the subaltern speak? In: Nelson \& Grossberg (eds) Marxism and the Interpretation of Culture (pp. 271-313). Basingstoke: Macmillan.

Stabile, Carole A. \& Deepa Kumar (2005) Unveiling Imperialism: Media, Gender and the War on Afghanistan. Media, Culture E Society 27 (5): 765-782. Stern, Maria (2005) Naming Security - Constructing Identity: 'Mayan Women' in Guatemala on the Eve of 'Peace'. Manchester: Manchester University Press.

Sundar, Nandini (2006). “Bastar, Maoism, and Salwa Judum." Economic and Political Weekly. 41 (29), 22 Jul, 2006 
Sylvester, Christine (2013) War as Experience: Contributions from International Relations and Feminist Analysis. London: Routledge

Wæver, Ole (1995) Securitization and Desecuritization. In: Ronnie D. Lipschutz (ed) On Security: New Directions in World Politics. New York: Columbia University Press.

Wibben, Annick T.R. 2011. Feminist Security Studies: A Narrative Approach. $\begin{array}{llll}\text { London } \quad \& \quad \text { New } & \text { York: }\end{array}$ --2016a. Researching War: Feminist Methods, Ethics \& Politics. London \& New York: Routledge

-- 2016b. Female Engagement Teams in Afghanistan: Exploring the 'War on Terror' Narrative. In: Researching War: Feminist Methods, Ethics E Politics (pp. 57-75). London \& New York: Routledge

-- 2016c. Opening security: Recovering critical scholarship as political. Critical Studies on Security 4(2): 137-53.

Zalewski, Marysia (2008) Distracted reflections on the production, narration, and refusal of feminist knowledge in International Relations. In: Ackerly, Brooke A., Stern, Maria, and True, Jacqui (Eds.) Feminist Methodologies for International Relations (pp 42- 61). Cambridge: Cambridge University Press.

Zehfuss, Maja. 2003. Forget September 11. Third World Quarterly 24(3): 513528. 